\title{
Characterization and evaluation of sensory acceptability of ice creams incorporated with beta-carotene encapsulated in solid lipid microparticles
}

\author{
Juliana Gobbi de LIMA, Thais Carvalho BRITO-OLIVEIRA ${ }^{1}$, Samantha Cristina de PINHO ${ }^{1 \star}$
}

\begin{abstract}
The feasibility of incorporating beta-carotene-loaded solid lipid microparticles (BCSLM) into vanilla ice creams was investigated, through the physico-chemical characterization and evaluation of sensory acceptability of the products products. The BCSLM were produced with palm stearin as the lipid phase, hydrolyzed soy protein isolate as the surfactant, and xanthan gum as the thickener. The results showed similar values of proximate composition, total soluble solids, $\mathrm{pH}$, and overrun for all formulations. On the other hand, colorimetric evaluations showed that the ice cream produced with partial substitution of artificial additives by BCSLM containing alpha-tocopherol presented a more intense color, while in the product with non-encapsulated beta-carotene, a fast degradation of carotenoid was confirmed, highlighting the importance of the encapsulation techniques. The results of the sensorial analysis of the products were highly satisfactory and showed that the panelists preferred the ice creams produced with BCSLM containing alpha-tocopherol and with partial substitution of artificial additives by BCSLM containing alpha-tocopherol, confirming the feasibility of incorporating BCSLM into ice creams to reduce the application of artificial dyes to the product.
\end{abstract}

Keywords: lipid particles; ice cream; palm stearin; microencapsulation; beta-carotene.

Practical Application: Incorporation of encapsulated beta-carotene into ice cream may reduce the use of artificial dyes.

\section{Introduction}

The interest of the food industry in the development of new products is constantly increasing and becoming more challenging, due to consumers' awareness about healthier foods (Dias et al., 2015). Different approaches have been developed for the incorporation of bioactives in foods and for the production of functional products, capable of providing a health benefit that goes beyond nutrition (Aboulfazli et al., 2015, 2016; Duchateau \& Klaffke, 2009).

Dairy products, such as ice creams and yogurts, are considered nutritious foods and present a great potential to incorporate bioactives (Aboulfazli et al., 2016; Leandro et al., 2013). Several studies in the literature have shown that ice creams are ideal matrices for the incorporation of ingredients with functional properties, such as probiotics (Aboulfazli et al., 2016; Ranadheera et al., 2013; Silva et al., 2015) and dietary fibers (Akbari et al., 2016; Hashemi et al., 2015; Leandro et al., 2013; Boff et al., 2013). Nevertheless, only a few studies have discussed the application of natural antioxidants, like curcuminoids and carotenoids, on this product (Kumar et al., 2016; Rizk et al., 2014; Sun-Waterhouse et al., 2013). The use of these natural coumpounds in ice creams would be advantageous due to two reasons: (i) the possible benefits to the health due to their antioxidant characteristics (Ratnam et al., 2006; Fraser \& Bramley, 2004); (ii) the possibility of replacement of artificial dyes, which are a recognized cause of some adverse reactions in the consumers (Moutinho et al., 2007).
Beta-carotene is a carotenoid, interesting for the food industry due to its red color and its functional properties, mostly related to the antioxidant capacity and pro-vitamin A activity (Cao-Hoang et al., 2010; Gonnet et al., 2010). Although exhibiting attractive characteristics, the application of beta-carotene in food products is challenging due to its high hydrophobicity, high chemical instability, and low bioavailability during digestion (Priamo et al., 2010). There are several factors affecting the stability of bioactives in their free form, but microencapsulation technologies can provide protection from factors such as light, moisture, heat, and oxygen (Dias et al., 2015).

As beta-carotene is highly lipophilic, its encapsulation in lipid-based matrices can be an interesting alternative to overcome the aforementioned drawbacks of incorporation and bioavailability. Among the lipid-based carriers that can be used in food, there are the solid lipid particles, which have structures similar to those of oil-in-water emulsions, where the oily core is replaced by a solid lipid at room temperature (Müller et al., 2000). Solid lipid particles are used to encapsulate and protect sensitive lipophilic compounds and present different advantages, such as low toxicity, possibility of controlling the release of the encapsulated compounds, low cost, and application of biocompatible and biodegradable solid lipids (Helgason et al., 2009; Mehnert $\&$ Mader, 2001). The encapsulation of beta-carotene in this type of lipid-based carrier has been already studied in the literature, with promising results (Gomes et al., 2013a, b; Cornacchia \& 
Roos, 2011; Hentschel et al., 2008). The coencapsulation of a "protective" molecule, such as alpha-tocopherol, was considered as essential to avoid beta-carotene degradation for longer periods (Gomes et al., 2013a, b).

In this context, and considering the lack of studies which investigate the application of solid lipid particles in dairy products, the objective of this study was to evaluate the feasibility of incorporating beta-carotene-loaded lipid microparticles into vanilla ice creams, through characterization and evaluation of sensory acceptability of products with four formulations: IC-1, IC-2 and IC-3 produced without artificial additives and IC-4 with partial substitution (50\%) of artificial additives. The vanilla flavor was chosen due to the possibility of replacing the artificial dye, responsible for the yellow color of the product, for BCSLM.

\section{Materials and methods}

\subsection{Chemicals and reagents}

For the production of the BCSLM, soy protein isolate (SPI, Supro ${ }^{\oplus} 780,81 \%$ protein) was obtained from The Solae Company (St. Louis, MO, USA), beta-carotene (BC) and alpha-tocopherol (TOC) were obtained from Sigma-Aldrich (St. Louis, MO, USA), palm stearin was donated by Agropalma (Belém, PA, Brazil), and xanthan gum (GRINDSTED ${ }^{\oplus}$ Xanthan 80 ) was donated by Danisco (Cotia, SP, Brazil). The other chemicals were of reagent grade. For the production of ice creams, the ingredients were whole milk (obtained from the dairy plant of the our School of Animal Science and Food Engineering, University of São Paulo), Algemix (vanilla ice cream base, obtained from Duas Rodas, Jaraguá do Sul, SC, Brazil), stabilizer and emulsifier obtained from Duas Rodas (Jaraguá do Sul, SC, Brazil), hydrogenated fat obtained from Bunge (Gaspar, SC, Brazil), and vanilla flavor obtained from Arcolor (São Paulo, SP, Brazil).

\subsection{Production of BCSLM}

The production of the BCSLM comprised two steps: solubilization of soy protein isolate and production of BCSLM. The solubilization step was performed by alkali-thermal treatment, which consisted of hydrating the soy protein isolate with ultrapure water to the desired concentration, followed by 30 min of magnetic stirring, adjusting the $\mathrm{pH}$ of the dispersion to 12 , and waiting for $30 \mathrm{~min}$ before heating the samples to $85{ }^{\circ} \mathrm{C}$ for $30 \mathrm{~min}$ in a water bath (Zhang et al., 2012). For the production of BCSLM, first, the palm stearin was maintained at $95{ }^{\circ} \mathrm{C}$ for $30 \mathrm{~min}$ in order to eliminate its thermal memory. The aqueous phase was produced with $1 \%(\mathrm{w} / \mathrm{v})$ of SPI and dispersed in the lipid phase $(5 \%, \mathrm{w} / \mathrm{v})$, both at $70{ }^{\circ} \mathrm{C}$, using a rotor-stator device (Ultra-Turrax IKA T25, IKA, Staufen, Germany) at 15,000 rpm for $5 \mathrm{~min}$. Afterward, during the cooling process of the dispersion up to room temperature, xanthan gum $(0.3 \%, \mathrm{w} / \mathrm{v})$ was added slowly using magnetic stirring. To avoid microbiological contamination, sodium benzoate $(0.02 \%, \mathrm{w} / \mathrm{v})$ was added to the samples. The beta-carotene $(0.023 \%, \mathrm{w} / \mathrm{v})$ and alpha-tocopherol $(0.012 \%, \mathrm{w} / \mathrm{v})$, when present, were added to the melted lipid phase. The samples were stored at $10^{\circ} \mathrm{C}$ in glass flasks, protected from light. The BCSLM without alpha-tocopherol were termed as BCSLM-1; the BCSLM with alpha-tocopherol were termed as BCSLM-2. The average particle size and the particle size distribution were evaluated using a laser diffraction analyzer (SALD-201 V, Shimadzu, Kyoto, Japan). The samples were diluted before analyses with deionized water.

\subsection{Production of the ice creams}

The formulations of ice creams were produced, according to Table 1. First, the milk was pasteurized and then transferred to an industrial blender, where sugar, milk powder, BCSLM (when present), refined sugar, stabilizer, and emulsifier were added and mixed. This mixture was produced $24 \mathrm{~h}$ before the homogenization step. After this period of maturation, the mixture was homogenized for $7 \mathrm{~min}$ and frozen. The ice creams were stored in a freezer at $-10^{\circ} \mathrm{C}$.

\subsection{Physicochemical characterization of the ice creams}

The ice creams were characterized in terms of proximate composition, $\mathrm{pH}$, total soluble solids, instrumental colorimetry, and overrun values. Regarding protein content, moisture content, and ash content, the analyses were conducted according to the official methods (Association of Oficial Analytical Chemists, 1997). Lipid content was determined according to Gerber's method (Kleyn et al., 2001), and carbohydrate content was evaluated as the remaining content of the ice cream. The color of the ice creams was determined using portable colorimeter (Miniscan XE, Hunterlab, Reston, VA, USA), and the parameters of the color system $\left(\mathrm{L}^{*} \mathrm{a}^{*} \mathrm{~b}^{\star}\right)$ were obtained by reflectance, an illuminator D65 with the observer at $10^{\circ}$, and the total color difference (TCD), chroma ( $\left.\mathrm{C}^{*} \mathrm{ab}\right)$, and hue angle $\left(\mathrm{H}^{*} \mathrm{ab}\right)$ parameters were calculated. The values of total soluble solids and $\mathrm{pH}$ were also determined. The values of overrun (calculation of the air added to the ice creams) were obtained from the comparison between

Table 1. Composition of the ice creams produced with different formulations.

\begin{tabular}{|c|c|c|c|c|}
\hline \multirow{2}{*}{ Ingredient } & \multicolumn{4}{|c|}{ Formulation } \\
\hline & IC-1 & IC-2 & IC-3 & IC-4 \\
\hline Milk (L) & 5 & 5 & 5 & 5 \\
\hline Sugar (g) & 900 & 900 & 900 & 900 \\
\hline Vanilla ice cream base $(\mathrm{g})$ & 500 & 500 & 500 & 500 \\
\hline $\begin{array}{l}\text { Commercial mix of dyes and } \\
\text { flavor-vanilla }(\mathrm{g})\end{array}$ & --- & --- & --- & 75 \\
\hline Hydrogenated vegetable fat (g) & 150 & 150 & 150 & 150 \\
\hline Emulsifier (g) & 50 & 50 & 50 & 50 \\
\hline Stabilizer (g) & 50 & 50 & 50 & 50 \\
\hline $\begin{array}{l}\text { Beta-carotene-loaded lipid } \\
\text { microparticles } \\
(\text { BCSLM- } 1)^{*}(\mathrm{~mL})\end{array}$ & --- & --- & 150 & --- \\
\hline $\begin{array}{l}\text { Beta-carotene-loaded lipid } \\
\text { microparticles } \\
(\text { BCSLM-2 })^{*}(\mathrm{~mL})\end{array}$ & --- & 150 & --- & 75 \\
\hline $\begin{array}{l}\text { Non-encapsulated beta-carotene } \\
(\mathrm{mg})\end{array}$ & 28 & & & \\
\hline Vanilla flavor (g) & 10 & 10 & 10 & --- \\
\hline
\end{tabular}

*The BCSLM without alpha-tocopherol were termed as BCSLM-1; the BCSLM with alpha-tocopherol were termed as BCSLM-2. 
the weights of the unfrozen mixtures and the final ice creams in a fixed volume container (Hart \& Fisher, 1971).

\subsection{Sensory evaluation of the ice creams}

Sensory evaluation of the ice creams was performed by affective tests, which were employed to evaluate consumer acceptance. The tests were performed on the samples within 1 week of storage. The panelists were asked to indicate how much they liked or disliked the ice creams based on the attributes flavor, taste, color, and global acceptance, according to a 9-point hedonic scale. Each sample was randomly coded with three-digit numbers. This research was submitted to and approved by the Ethics Research Committee from FZEA/USP (code CAAE 41462115.4.0000.5422 SCP), and the participants signed a Term of Consent.

\subsection{Statistical analyses}

The average values obtained from the treatments were compared using Tukey's test, with a 5\% $(\mathrm{p}<0.05)$ significance level on SAS software, version 9.2.

\section{Results and discussion}

\subsection{Physicochemical characterization of the ice creams}

The visual aspects of the dispersions of BCSLM used for the production of ice creams are shown in Figure 1A. These samples presented high stability, with average diameters between $1.20 \mu \mathrm{m}$ and $1.70 \mu \mathrm{m}$, over 45 days of storage. The different formulations of vanilla ice cream presented satisfactory visual aspects, as shown in Figure 1. The samples were analyzed in terms of proximate composition, total soluble solids, $\mathrm{pH}$, and overrun, and the values obtained are shown in Table 2. These results indicated that the analyzed characteristics were similar for all formulations. Due to the lack of studies which investigate the application of solid lipid particles or free beta-carotene in ice creams, the comparison of the obtained results with the literature is complex.

The proximate composition of the ice creams has a direct influence on the state of fat globule aggregation, the amount of incorporated air, the viscosity of the aqueous phase, the size of ice crystals, and, consequently, the sensory acceptance of the final product (Dickinson \& Stainsby, 1982). In the present study, the results of proximate composition analysis showed that the ice creams IC- 3 and IC- 4 presented higher contents of carbohydrates and fats than IC-1 and IC-2, with no significant differences between the average values.

Erkaya et al. (2012) studied the influence of Cape gooseberry (Physalis peruviana L.) addition on the characteristics of ice cream, and found similar results of fat content, around 3.7\%. On the other hand, Rizk et al. (2014) studied the influence of the addition of lycopene extracted from tomato on the characteristics of ice cream, and obtained values of fat content between 8 and $8.58 \%$. Similarly, Sun-Waterhouse et al. (2013) verified fat contents around $9.5 \%$ in ice creams produced with juice from kiwifruit with green, gold or red flesh. According to these authors, even ice creams with fat content around $9.5 \%$ can be classified as low-fat products. Fat content is important for conferring creamy and smooth texture, for increasing the viscosity, and also for increasing the melting resistance of the ice cream (Mosquim, 1999; Pinheiro \& Penna, 2004; Souza et al., 2010), but low fat products can be interesting once. According to Silva et al. (2014) the influence of concern about health should also be considered for the success of the ice creams on the market.

Carbohydrates also contribute to increasing the viscosity and the softness of the product, but they tend to increase the melting rate and influence the size of lactose crystals in the ice cream (Mosquim, 1999; Pinheiro \& Penna, 2004; Souza et al., 2010).

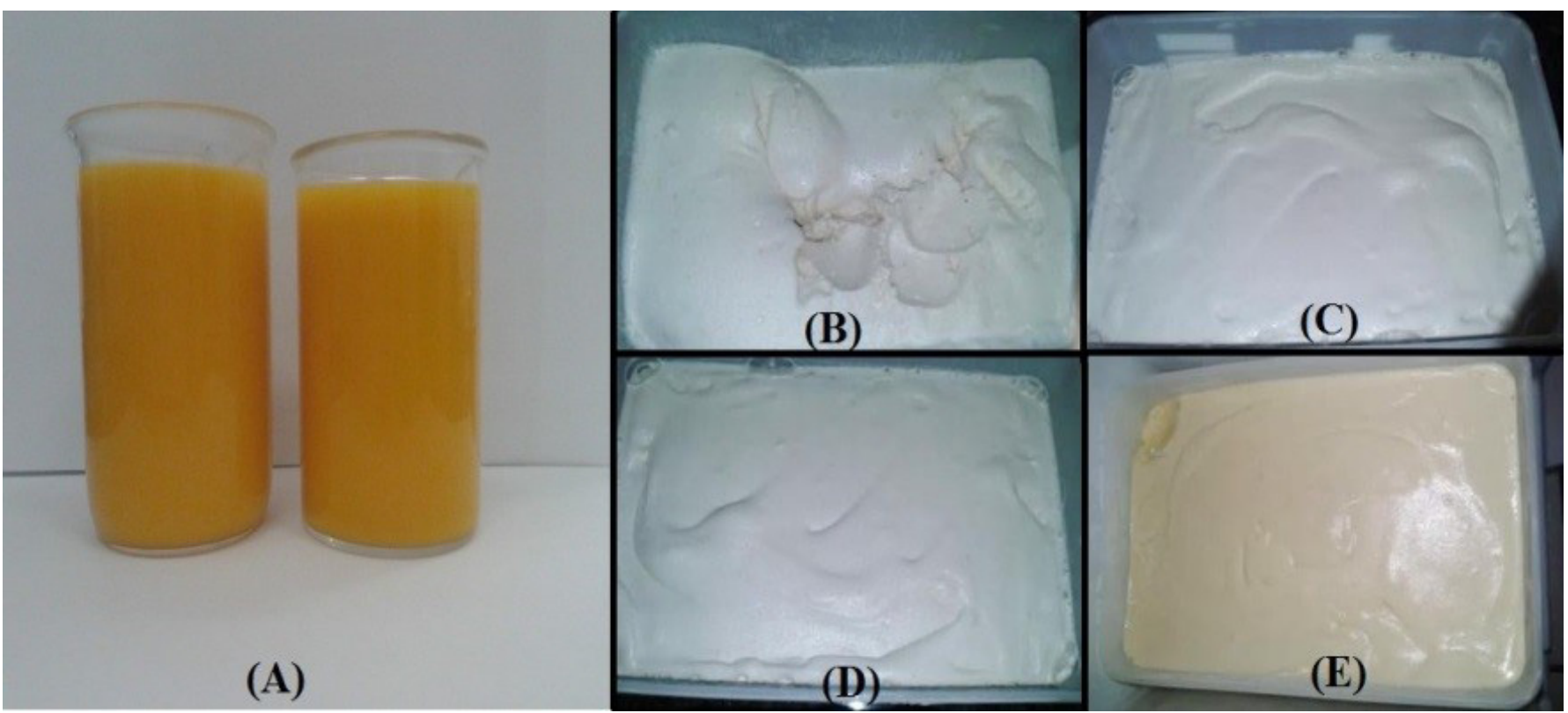

Figure 1. Visual aspects of the BCSLM (A) and the ice creams produced with formulations IC-1 (B), IC-2 (C), IC-3 (D), and IC-4 (E). 
Lima; Brito-Oliveira; Pinho

Table 2. Results of the characterizations of ice creams produced with different formulations.

\begin{tabular}{lcrrr}
\hline \multirow{2}{*}{ Parameter } & \multicolumn{3}{c}{ Formulation } \\
\cline { 2 - 5 } & \multicolumn{1}{c}{ IC-1 } & IC-2 & IC-3 & IC-4 \\
\hline Moisture (\%) & $69.01 \pm 0.06^{\mathrm{a}}$ & $69.05 \pm 0.21^{\mathrm{a}}$ & $24.84 \pm 0.07^{\mathrm{b}}$ & $68.58 \pm 0.03^{\mathrm{b}}$ \\
Carbohydrate (\%) & $24.43 \pm 0.01^{\mathrm{b}}$ & $24.37 \pm 0.05^{\mathrm{b}}$ & $2.58 \pm 0.02^{\mathrm{b}}$ & $24.71 \pm 0.04^{\mathrm{a}}$ \\
Protein (\%) & $2.62 \pm 0.01^{\mathrm{ab}}$ & $2.65 \pm 0.02^{\mathrm{a}}$ & $3.50 \pm 0.01^{\mathrm{a}}$ & $2.68 \pm 0.04^{\mathrm{a}}$ \\
Fat (\%) & $3.40 \pm 0.01^{\mathrm{b}}$ & $3.40 \pm 0.01^{\mathrm{b}}$ & $0.53 \pm 0.02^{\mathrm{a}}$ & $3.50 \pm 0.01^{\mathrm{a}}$ \\
Ash (\%) & $0.54 \pm 0.02^{\mathrm{a}}$ & $0.53 \pm 0.01^{\mathrm{a}}$ & $30.50 \pm 0.01^{\mathrm{a}}$ & $0.53 \pm 0.10^{\mathrm{a}}$ \\
Total soluble solids ( ${ }^{\circ}$ Brix) & $30.50 \pm 0.01^{\mathrm{a}}$ & $30.00 \pm 0.01^{\mathrm{b}}$ & $6.75 \pm 0.02^{\mathrm{a}}$ & $28.90 \pm 0.02^{\mathrm{c}}$ \\
pH & $6.50 \pm 0.01^{\mathrm{c}}$ & $6.60 \pm 0.01^{\mathrm{d}}$ & $239^{\mathrm{a}}$ & $6.65 \pm 0.01^{\mathrm{b}}$ \\
Overrun (\%) & $209^{\mathrm{d}}$ & $219^{\mathrm{c}}$ & $244^{\mathrm{b}}$ \\
\hline
\end{tabular}

Mean values followed by different lowercase letters in the same row are statistically different $(\mathrm{p}<0.05)$.

Samples of ice creams IC-1 and IC-2 presented higher moisture contents than IC-3 and IC-4, and all formulations presented averages higher than the value found in the literature for vanilla ice creams, which is, approximately, 61.7\% (Arbuckle, 1986). According to Pinheiro \& Penna (2004), such results were expected, as in ice creams, the higher the amount of fat, the lower the amount of water.

No statistically significant differences were observed in the protein contents of the ice creams IC-1, IC-2, and IC-4, but these values were higher than those obtained from analyses of the products with formulation IC-3. All formulations presented protein contents lower than the averages found in the literature, around 4\% (Arbuckle, 1986; Erkaya et al., 2012). Proteins are considered essential ingredients in ice creams, important to the stabilization of the emulsion after homogenization, to the formation of the product structure, and to the water-holding capacity, which improves the viscosity of the mixtures, reduces ice formation, and increases the melting resistance of the product (Arbuckle, 1986; Souza et al., 2010).

The obtained results indicate that the proximate composition of the ice creams was not highly affected by the incorporation of BCSLM and that all formulations tested were in accordance with Brazilian regulations, which determine that ice creams must present a minimum of $28 \%$ of total solids, $3 \%$ of fat, and $2.5 \%$ of protein (Agência Nacional de Vigilância Sanitária, 1999, 2005).

Another important physicochemical characteristic of the ice creams is the overrun, which can be defined as the increase of product's volume in relation to the liquid mix used to produce it, in percentage. This parameter is related to the amount of air incorporated into the ice cream during the production and, consequently, interferes with the texture and physical properties of melting and hardness of the product (Cruz et al., 2009; Sofjan \& Hartel, 2004). The overrun values, which varied from 209 (IC-1) to $244 \%$ (IC-4), were higher than the values found in the literature, which varies from 34 to $97 \%$ (Rizk et al., 2014; Erkaya et al., 2012; Sun-Waterhouse et al., 2013). According to Sun-Waterhouse et al. (2013) a higher fat content could have enabled a higher overrun, once more coalesced fat droplets would be available to trap a greater amount of air bubbles in the product. Besides the fat content, the protein content is also important for ice creams overrun, once it contribute to air interfaces stabilization (Turan et al., 1999). As shown in Table 2, ice creams incorporated with BCSLM (IC-2, IC-3, and
IC-4) showed overrun values higher than those of IC-1. These results indicate that the presence of free beta-carotene may have decreased the capacity of the systems to incorporate air. Similar results were obtained by Rizk et al. (2014), who observed a decrease of overrun with the increase of carotenoids in ice creams. According to these authors, the decrease of overrun may be attributed to increase the mix viscosity, which affects on whipping rate of mixes.

The values of $\mathrm{pH}$ were similar for all the formulations tested, although the averages presented statistical differences $(\mathrm{p}<0.05)$. The ice creams IC- 1 showed the lowest $\mathrm{pH}$ value (6.5), whereas IC-3 showed the highest (6.75) $\mathrm{pH}$ value, in comparison to the other formulations, indicating that the presence of free beta-carotene and BCSLM promoted a decrease in this parameter. Similarly, Rizk et al. (2014) verified a slightly decrease of $\mathrm{pH}$ in their study of incorporation of lycopene in ice creams. According to Marshall et al. (2003), the $\mathrm{pH}$ of ice creams varies with the composition of the product, but, in general, it is in the range of 6.3-6.5. The $\mathrm{pH}$ value is an important parameter, as it is related to the composition of the ice creams, specially milk proteins, mineral salts and dissolved gases. High acidity of ice creams can be caused by the production of lactic acid by bacteria, and it is undesirable as it contributes to increase viscosity, decrease whipping rate, inferior flavor and less stable mix, which may result in coagulation during the processing procedure (Arbuckle, 1986).

The results of total soluble solids were also similar for all the formulations tested, varying from $28.9^{\circ}$ Brix in formulation IC- 4 to $30.5^{\circ}$ Brix in formulations IC- 1 and IC-3, which are adequate values according to the literature (Tamime, 2007). Those solids are mostly derived from sugars, milk-solids-non-fat (SNF) and additional ingredients, such as stabilizers and emulsifiers. The control of total soluble solids is important, as it is an indicative of the balance among ice creams ingredients, which is very important for ice cream quality, influencing, for example, on lactose crystallization (Tamime, 2007).

Regarding the colorimetric parameters of the ice creams, they were monitored during 45 days of storage, and they provided an indirect measurement of the stability of the beta-carotene present in the dairy product. According to Pathare et al. (2013), color measurement of food products can be used as an indirect measurement of pigment content and flavor, with the advantage of being also simple and quick to be obtained. Through the values of $b^{*}, a^{*}$, and $L^{*}$, shown in Table 3 , the values of Chroma 
Table 3. Values of the colorimetric parameters $\mathrm{b}^{\star}, \mathrm{a}^{\star}$, and $\mathrm{L}^{\star}$ of the ice creams produced with different formulations, during the storage period.

\begin{tabular}{|c|c|c|c|c|}
\hline Formulation & Day & $b^{*}$ & $a^{*}$ & $\mathrm{~L}^{*}$ \\
\hline \multirow{3}{*}{ IC-1 } & 1 & $14.11 \pm 0.08^{\mathrm{bcD}}$ & $1.81 \pm 0.08^{\mathrm{aC}}$ & $81.29 \pm 0.05^{\mathrm{bA}}$ \\
\hline & 15 & $14.61 \pm 0.24^{\mathrm{aC}}$ & $1.46 \pm 0.24^{\mathrm{bC}}$ & $79.77 \pm 0.57^{\mathrm{cA}}$ \\
\hline & 30 & $14.44 \pm 0.12^{\mathrm{abD}}$ & $1.31 \pm 0.08^{\mathrm{bcc}}$ & $80.25 \pm 0.24^{\mathrm{cB}}$ \\
\hline \multirow{2}{*}{ IC-2 } & 1 & $18.13 \pm 0.13^{\mathrm{abB}}$ & $3.43 \pm 0.04^{\mathrm{aB}}$ & $79.86 \pm 0.24^{\mathrm{eB}}$ \\
\hline & 15 & $17.82 \pm 0.63^{\mathrm{abcB}}$ & $2.97 \pm 0.19^{\mathrm{bB}}$ & $78.78 \pm 0.13^{\mathrm{bB}}$ \\
\hline \multirow{4}{*}{ IC-3 } & 1 & $17.59 \pm 0.05^{\mathrm{bcC}}$ & $3.25 \pm 0.18^{\mathrm{bB}}$ & $80.15 \pm 0.03^{\mathrm{bB}}$ \\
\hline & 15 & $18.23 \pm 0.21^{\mathrm{abB}}$ & $2.93 \pm 0.07^{\mathrm{cB}}$ & $80.08 \pm 0.17^{\mathrm{bcA}}$ \\
\hline & 30 & $17.47 \pm 0.64^{\mathrm{bcC}}$ & $3.31 \pm 0.08^{\mathrm{bB}}$ & $79.77 \pm 0.18^{\mathrm{cC}}$ \\
\hline & 45 & $15.35 \pm 0.04^{\mathrm{dC}}$ & $2.87 \pm 0.01^{\mathrm{eB}}$ & $77.92 \pm 0.02^{\mathrm{dB}}$ \\
\hline IC-4 & 1 & $34.41 \pm 0.23^{\mathrm{bcA}}$ & $6.49 \pm 0.15^{\mathrm{aA}}$ & $78.91 \pm 0.08^{\mathrm{bC}}$ \\
\hline
\end{tabular}

Mean values followed by different lowercase letters in the same column are statistically different $(\mathrm{p}<0.05)$ for the same formulation on different days of analysis. Mean values followed by different capital letters in the same column are statistically different $(\mathrm{p}<0.05)$ for different formulations on the same day of analysis.

$\left(\mathrm{C}^{\star} \mathrm{ab}\right)$, Hue angle $\left(\mathrm{H}^{\star} \mathrm{ab}\right)$, and total color difference $(\mathrm{TCD})$ were calculated for all formulations, as shown in Figures 2A-C.

The parameter $\mathrm{a}^{*}$ represents the variation of the color from red (positive values) to green (negative values), the parameter $\mathrm{b}^{*}$ represents the variation of the color from yellow (positive values) to blue (negative values), and the parameter $\mathrm{L}^{*}$ represents luminosity, which varies from black to white (Granato \& Masson, 2010; Pathare et al., 2013). All the ice creams tested had positive values of $\mathrm{a}^{\star}$ and $\mathrm{b}^{*}$, which decreased over the 45 days of storage. Samples of ice cream IC-4 presented significantly higher values of $\mathrm{a}^{*}$ and $\mathrm{b}^{*}$ than the other formulations, whereas IC- 1 samples showed lower values. On the other hand, the parameter $\mathrm{L}^{*}$ was higher for samples with formulation IC-1 and lower for those with formulation IC-4. These primary colorimetric values were used to calculate Chroma ( $\left.\mathrm{C}^{\star} \mathrm{ab}\right)$, Hue angle $\left(\mathrm{H}^{\star} \mathrm{ab}\right)$ and total color difference (TCD), which can be used to evaluate the real impact of the encapsulation of the beta-carotene on its degradation along the storage period.

According to Pathare et al. (2013), Chroma ( $\left.C^{\star} a b\right)$ is a quantitative attribute of colorfulness, which indicates the color intensity perceived by humans. The values of chroma shown in Figure 2A indicated higher values for IC-4 presented the highest values during the storage period, whereas products with formulation IC-1 presented the lowest. Such a result indicated consumers would be able to perceive the difference between the color intensity of the samples prepared with free beta-carotene and the color intensity of the samples prepared with partial substitution of artificial additives by BCSLM containing alpha-tocopherol. However, the samples with formulations IC-2 and IC-3 showed similar values over the whole storage period. However, the values of chroma of all ice creams decreased over the 45 days of storage, indicating that the oxidation of beta-carotene may have occurred and, consequently, the color change in all formulations could be perceived. Regarding Hue angle $\left(\mathrm{H}^{\star} \mathrm{ab}\right)$, which is a qualitative attribute of color, are shown in Figure 2B. These results showed that samples with formulation IC-1 presented significantly higher values over all days of storage, and other formulations presented significant differences among the mean values only on day 3 , when the value of the Hue angle of the samples with formulation IC-3 was lower. For all samples, this parameter remained constant over the 45 days, with values in the range of $85-95^{\circ}$, in the region of yellow, as suitable for a vanilla ice cream.

Based on the analysis of the values of total color difference (TCD), depicted in Figure 2C, it was verified that, after 45 days of storage, the ice cream IC-1 presented lower values than the other samples. According to the theory of colors magnitude described by Francis \& Clydesdale (1975), values of TCD equal or higher than 2 are visually perceptible. Therefore, in the present study, only the ice creams IC-1 did not show perceptible color variation after 45 days of storage. However, as TCD indicates only the variation of colorimetric parameters between the first day of storage and the moment of the analysis and, it does not consider possible deteriorations of beta-carotene during the production of the ice cream and during the time interval between the production and the first colorimetric evaluation. In this context, it is necessary to consider the other colorimetric parameters to understand the results. On the first day of storage, the samples of IC-1 already presented higher values of $\mathrm{L}^{*}$ and Hue angle, around 81 and $92^{\circ}$, respectively, and lower values of $C^{\star} a b$, around 14 , indicating a yellowish orange color, with an appearance more pale than the other formulations. These results indicate that the beta-carotene deterioration possibly started during the manufacturing process of the ice-cream IC-1, highlighting the importance of encapsulation techniques.

\subsection{Sensory analysis of the ice creams with BCSLM}

The results of the sensory analysis of the ice creams with different formulations are shown in Table 4. These results showed that the grades conferred to the flavor of the four ice creams were not significantly different. On the other hand, 


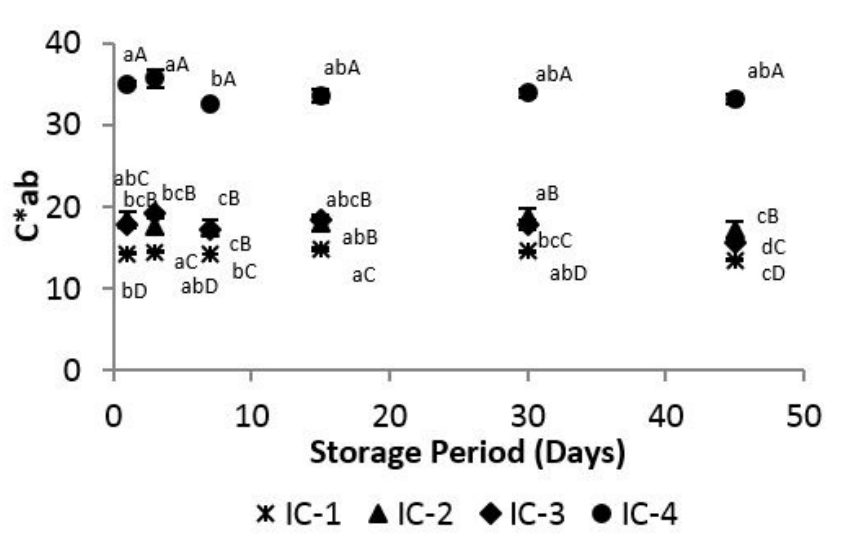

(A)

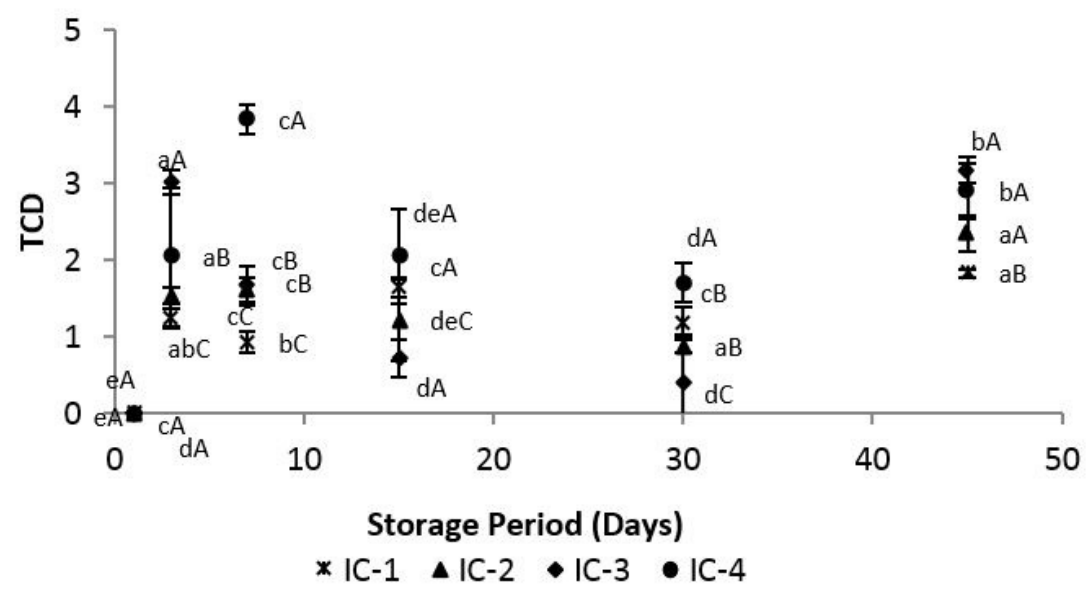

(C)

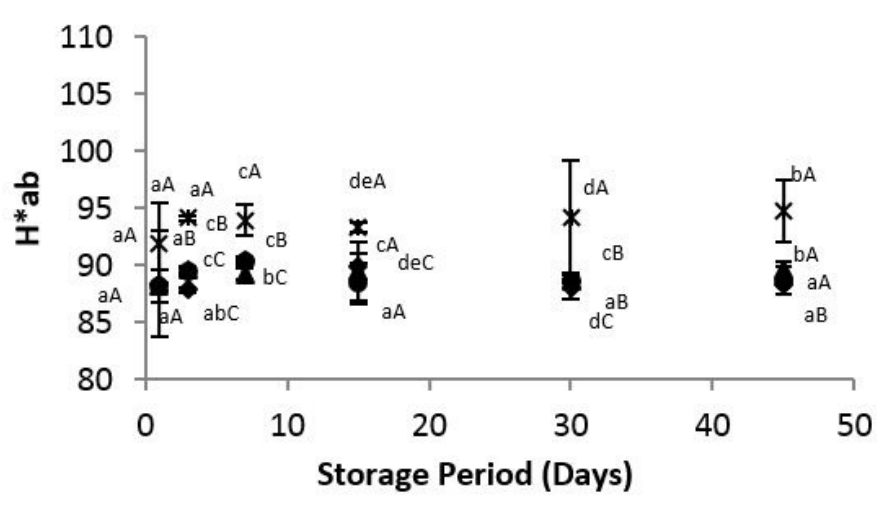

*IC-1 $\Delta$ IC-2 $\bullet$ IC-3 $\bullet$ IC-4

(B) 
visual aspects and the results of physicochemical analyses were similar for all the formulations tested, indicating that the analyzed characteristics were not drastically affected by the incorporation of BCSLM. Moreover, the colorimetric evaluations of the ice creams confirmed the importance of beta-carotene encapsulation in solid lipid microparticles to obtain a product with a longer stability. Data obtained in sensory evaluation were promising, indicating that the panelists approved the ice creams with BCSLM containing alpha-tocopherol (IC-2) and with partial substitution of artificial additives by BCSLM containing alpha-tocopherol (IC-4).

\section{Acknowledgements}

The authors thank $\mathrm{CNPq}$ (Brazil) for the financial support of the project (grant number 471689/2012-2), University of São Paulo (Pró-Reitoria de Pesquisa/USP), for the fellowship of Juliana G. Lima, and FAPESP (fellowship 2012/10367-6 for Thais C. Brito-Oliveira). The authors also thank Agropalma and Danisco for donating the palm stearin and xanthan gum, respectively.

\section{References}

Aboulfazli, F., Baba, A. S., \& Misran, M. (2015). Effects of fermentation by Bifidobacterium bifidum on the rheology and physical properties of ice cream mixes made with cow and vegetable milks. International Journal of Food Science \& Technology, 50(4), 942-949. http://dx.doi. org/10.1111/ijfs.12723.

Aboulfazli, F., Shori, A. B., \& Baba, A. S. (2016). Effects of the replacement of cow milk with vegetable milk on probiotics and nutritional profile of fermented ice cream. LWT - Food Science and Technology, 70(1), 261-270. http://dx.doi.org/10.1016/j.lwt.2016.02.056.

Agência Nacional de Vigilância Sanitária - ANVISA. (1999, April 26). Portaria $n^{\circ} 379$, de 26 de abril de 1999. Regulamento técnico referente a gelados comestíveis, preparados, pós para o preparo e bases para gelados comestíveis. Diário Oficial da União.

Agência Nacional de Vigilância Sanitária - ANVISA. (2005, September 23). Resolução no 266 de 22 de setembro de 2005. Regulamento técnico para fixação de identidade e qualidade de gelados comestíveis e, preparados para gelados comestíveis, pós para o preparo e bases para gelados comestíveis. Diário Oficial da União.

Akbari, M., Eskandari, M. H., Niakosari, M., \& Bedeltavana, A. (2016). The effect of inulin on the physicochemical properties and sensory attributes of low-fat ice cream. International Dairy Journal, 57(1), 52-55. http://dx.doi.org/10.1016/j.idairyj.2016.02.040.

Arbuckle, W. S. (1986). Ice cream (4rd ed.). Westport: AVI Publishing.

Association of Oficial Analytical Chemists - AOAC. (1997) Official methods of analysis of the Association of Official Analytical Chemists. Washington: AOAC.

Boff, C. C., Crizel, T. M., Araujo, R. R., Rios, A. O., \& Flôres, S. H. (2013). Development of chocolate ice cream using orange peel fiber as fat replacer. Ciência Rural, 43(10), 1892-1897. http://dx.doi. org/10.1590/S0103-84782013001000026.

Cao-Hoang, L., Fougere, R., \& Wache, Y. (2010). Increase in stability and change in supramolecular structure of beta-carotene through encapsulation into polylactic acid nanoparticles. Food Chemistry, 124(1), 42-49. http://dx.doi.org/10.1016/j.foodchem.2010.05.100.

Cornacchia, L., \& Roos, Y. H. (2011). Stability of $\beta$-carotene in proteinstabilized oil-in-water delivery systems. Journal of Agricultural and
Food Chemistry, 59(13), 7013-7020. PMid:21591770. http://dx.doi. org/10.1021/jf200841k.

Cruz, A. G., Antunes, A. E. C., Sousa, A. L. O. P., Faria, J. A. F., \& Saad, S. M. I. (2009). Ice cream as a probiotic food carrier. Food Research International, 42(9), 1233-1239. http://dx.doi.org/10.1016/j. foodres.2009.03.020.

Dias, M. I., Ferreira, I. C. F. R., \& Barreiro, M. F. (2015). Microencapsulation of bioactives for food applications. Food \& Function, 6(4), 1035-1052. PMid:25710906. http://dx.doi.org/10.1039/C4FO01175A.

Dickinson, E., \& Stainsby, G. (1982). Colloids in foods (382 p.). London: Applied Science Publishers.

Duchateau, G. S. M. J. E., \& Klaffke, W. (2009). Health food product composition, structure and bioavailability. In D. J. McClements \& E. A. Decker (Eds.), Designing functional foods (pp. 648-675). Boca Raton: CRC Press. http://dx.doi.org/10.1533/9781845696603.3.647.

Erkaya, T., Dağdemir, E., \& Şengül, M. (2012). Influence of Cape gooseberry (Physalis peruviana L.) addition on the chemical and sensory characteristics and mineral concentrations of ice cream. Food Research International, 45(1), 331-335. http://dx.doi.org/10.1016/j. foodres.2011.09.013.

Francis, J. F., \& Clydesdale, F. M. (1975). Food colorimetry, theory and application. New York: Van Nostrand Reinhold/AVI.

Fraser, P. D., \& Bramley, P. M. (2004). The biosynthesis and nutritional uses of carotenoids. Progress in Lipid Research, 43(3), 228-265. PMid:15003396. http://dx.doi.org/10.1016/j.plipres.2003.10.002.

Gomes, G. V. L., Borrin, T. R., Cardoso, L. P., Souto, E., \& Pinho, S. C. (2013a). Characterization and shelf life of $\beta$-carotene loaded solid lipid microparticles produced with stearic acid and sunflower oil. Brazilian Archives of Biology and Technology, 56(4), 663-671. http:// dx.doi.org/10.1590/S1516-89132013000400017.

Gomes, G. V. L., Simplício, I. A. S., Souto, E. B., Cardoso, L. P., \& Pinho, S. C. (2013b). Development of a lipid particle for beta-carotene encapsulation using a blend of tristearin and sunflower oil, choice of the lipid matrix and evaluation of the shelf life of dispersions. Food Technology and Biotechnology, 51, 383-391.

Gonnet, M., Lethuaut, L., \& Boury, F. (2010). New trends in encapsulation of liposoluble vitamins. Journal of Controlled Release, 146(3), 276-290. PMid:20600399. http://dx.doi.org/10.1016/j.jconrel.2010.01.037.

Granato, D., \& Masson, M. L. (2010). Instrumental color and sensory acceptance of soy-based emulsions, a response surface approach. Ciência e Tecnologia de Alimentos, 30(4), 1090-1096. http://dx.doi. org/10.1590/S0101-20612010000400039.

Hart, F. L., \& Fisher, H. J.(1971). Modern food analysis (144 p.). New York: Springer-Verlag. http://dx.doi.org/10.1007/978-3-642-87521-2.

Hashemi, M., Gheisari, H. R., \& Shekarforoush, S. (2015). Preparation and evaluation of low-calorie functional ice cream containing inulin, lactulose and Bifidobacterium lactis. International Journal of Dairy Technology, 68(2), 183-189. http://dx.doi.org/10.1111/1471-0307.12173.

Helgason, T., Awad, T. S., Kristbergsson, K., Decker, E. A., McClements, D. J., \& Weiss, J. (2009). Impact of Surfactant Properties on Oxidative Stability of $\beta$-Carotene Encapsulated within Solid Lipid Nanoparticles. Journal of Agricultural and Food Chemistry, 57(17), 8033-8040. PMid:19691283. http://dx.doi.org/10.1021/jf901682m.

Hentschel, A., Gramdorf, S., Müller, R. H., \& Kurz, T. (2008). $\beta$-Caroteneloaded nanostructured lipid carriers. Journal of Food Science, 73(2), 1-6. PMid:18298743. http://dx.doi.org/10.1111/j.1750-3841.2007.00641.x.

Kleyn, D. H., Lynch, J. M., Barbano, D. M., Bloom, M. J., \& Mitchell, M. W. (2001). Determination of fat in raw and processed milks by the gerber method: collaborative study. Journal of AOAC International, 84(5), 1499-1508. PMid:11601470. 
Kumar, D. D., Mann, B., Pothuraju, R., Sharma, R., Bajaj, R., \& Minaxi, (2016). Formulation and characterization of nanoencapsulated curcumin using sodium caseinate and its incorporation in ice cream. Food \& Function, 7(1), 417-424. PMid:26501983. http:// dx.doi.org/10.1039/C5FO00924C.

Leandro, E. S., Araújo, E. A., Conceição, L. L., Moraes, C. A., \& Carvalho, A. F. (2013). Survival of Lactobacillus delbrueckii UFV H2b20 in ice cream produced with different fat levels and after submission to stress acid and bile salts. Journal of Functional Foods, 5(1), 503-507. http://dx.doi.org/10.1016/j.jff.2012.10.003.

Marshall, R. T., Goff, H. D., \& Hartel, R. W. (2003). Ice cream (6th ed.). New York: Kluwar Academic. http://dx.doi.org/10.1007/9781-4615-0163-3.

Mehnert, W., \& Mader, K. (2001). Solid lipid nanoparticles Production, characterization and applications. Advanced Drug Delivery Reviews, 47(2-3), 165-196. PMid:11311991. http://dx.doi.org/10.1016/S0169409X(01)00105-3.

Mosquim, M. C. A. (1999). Fabricando sorvete com qualidade (62 p.). São Paulo: Varela.

Moutinho, I. L. D., Bertges, L. C., \& Assis, R. V. C. (2007). Prolonged use of the food dye tartrazine (FD\&C Yellow No 5) and its effects on the gastric mucosa of Wistar rats. Brazilian Journal of Biology = Revista Brasileira de Biologia, 67(1), 141-145. PMid:17505761. http://dx.doi.org/10.1590/S1519-69842007000100019.

Müller, R. H., Mäder, K., \& Gohla, S. (2000). Solid lipid nanoparticles (SLN) for controlled drug delivery, a review of the state of the art. European Journal of Pharmaceutics and Biopharmaceutics, 50(1), 161-177. PMid:10840199. http://dx.doi.org/10.1016/S09396411(00)00087-4.

Pathare, P. B., Opara, U. L., \& Al-Said, F. A. (2013). Colour Measurement and Analysis in Fresh and Processed Foods, A Review. Food Bioprocess Technology, 6(1), 36-60. http://dx.doi.org/10.1007/s11947-012-0867-9.

Pinheiro, M. V. S., \& Penna, A. L. B. (2004). Substitutos de gordura, tipos e aplicações em produtos lácteos. Alimentos e Nutrição, 15(2), 175-186.

Priamo, W. L., Cezaro, A. M., Ferreira, S. R. S., \& Oliveira, J. V. (2010). Precipitation and encapsulation of $\beta$-carotene in PHBV using carbon dioxide as anti-solvent. The Journal of Supercritical Fluids, 54(1), 103-109. http://dx.doi.org/10.1016/j.supflu.2010.02.013.

Ranadheera, C. S., Evans, C. A., Adams, M. C., \& Baines, S. K. (2013). Production of probiotic ice cream from goat's milk and effect of packaging materials on product quality. Small Ruminant Research, 112(1-3), 174-180. http://dx.doi.org/10.1016/j.smallrumres.2012.12.020.

Ratnam, D. V., Ankola, D. D., Bhardwaj, V., Sahana, D. K., \& Kumar, M. N. V. R. (2006). Role of antioxidants in prophylaxis and therapy: a pharmaceutical perspective. Journal of Controlled Release, 113(3), 189207. PMid:16790290. http://dx.doi.org/10.1016/j.jconrel.2006.04.015.

Rizk, E. M., El-Kady, A. T., \& El-Bialy, A. R. (2014). Charactrization of carotenoids (lyco-red) extracted from tomato peels and its uses as natural colorants and antioxidants of ice cream. Annals of Agricultural Science, 59(1), 53-61. http://dx.doi.org/10.1016/j.aoas.2014.06.008.

Silva, J. C., Borrin, T. R., Ruy, P., Brito, T. C., Pinheiro, A. C., Vicente, A. A., \& Pinho, S. C. (2014). Characterization, physicochemical stability, and evaluation of in vitro digestibility of solid lipid microparticles produced with palm kernel oil and tristearin. Food Science and Technology, 34(3), 532-538. http://dx.doi.org/10.1590/1678-457X.6359.

Silva, P. D. L., Bezerra, M. F., Santos, K. M. O., \& Correia, R. T. P. (2015). Potentially probiotic ice cream from goat's milk, Characterization and cell viability during processing, storage and simulated gastrointestinal conditions. LWT - Food Science and Technology, 62(1), 452-457. http://dx.doi.org/10.1016/j.lwt.2014.02.055.

Sofjan, R., \& Hartel, R. W. (2004). Effects of overrun on structural and physical characteristics of ice-cream. International Dairy Journal, 14(3), 255-262. http://dx.doi.org/10.1016/j.idairyj.2003.08.005.

Souza, J. C. B., Costa, M. R., de Rensis, C. M. V. B., \& Sivieri, K. (2010). Sorvete, composição, processamento e viabilidade da adição de probiótico. Alimentos e Nutrição, 21(1), 155-165.

Sun-Waterhouse, D., Edmonds, L., Wadhwa, S. S., \& Wibisono, R. (2013). Producing ice cream using a substantial amount of juice from kiwifruit with green, gold or red flesh. Food Research International, 50(2), 647-656. http://dx.doi.org/10.1016/j.foodres.2011.05.030.

Tamime, A. Y. (2007). Structure of dairy products. Oxford: Society of Dairy Technology Book Series.

Turan, S., Kirkland, M., Trusty, P. A., \& Campbell, I. (1999). Interaction of fat and air in ice cream. Dairy Industries International, 64, 27-31.

Zhang, J., Liang, L., Tian, Z., Chen, L., \& Subirade, M. (2012). Preparation and in vitro evaluation of calcium-induced soy protein isolate nanoparticles and their formation mechanism study. Food Chemistry, 133(2), 390-399. PMid:25683411. http://dx.doi.org/10.1016/j. foodchem.2012.01.049. 